\title{
Daniela Lauria* Discursive practices control in Spanish language
}

https://doi.org/10.1515/ijsl-2020-0059

Received August 3, 2020; accepted September 2, 2020

\begin{abstract}
Control mechanisms for written, spoken, and multimodal discursive practices are, in my view, a priority item on today's strategy agenda for a socially conscious approach to language in the peripheral countries of the global economic system. After describing and analyzing certain procedures for discursive regulation in Spanish language, and adopting the critical focus that glottopolitics provides, I zero in on the effects of this regulation and the subjectivities it shapes. Discursive restraints stem from several, often interconnected, sources: market dynamics, the search for greater productivity in the technologizing of the word, digital platforms, and as a condition for the approval of country loans by international economic organizations. The aim is to emphasize how discursive control reproduces the established social order and thus reinforces linguistic inequality.
\end{abstract}

Keywords: discourse control; globalization; glottopolitics; Spanish language; subjectivities

Resumen: Uno de los temas prioritarios de la agenda estratégica para un abordaje socialmente relevante del lenguaje en los países periféricos del sistema (economía)-mundo actual es, desde mi perspectiva, la cuestión de los dispositivos de control de las prácticas discursivas escritas, orales y multimodales. Mediante la adopción de un enfoque crítico como es el glotopolítico, luego de relevar y describir algunos procedimientos de regulación discursiva en español, me detengo en remarcar cuáles son los efectos que esto trae aparejado y cuáles son las subjetividades que se modelan. Los condicionamientos discursivos provienen, en algunos casos de forma articulada, de las dinámicas del mercado, de la búsqueda de mayor productividad de las tecnologías de la palabra y las plataformas digitales, y como contrapartida del otorgamiento de préstamos por parte de los organismos internacionales de crédito. Se intenta destacar, así, cómo el disciplinamiento discursivo reproduce el orden social establecido y refuerza, por consiguiente, la desigualdad lingüística.

*Corresponding author: Daniela Lauria, Universidad de Buenos Aires/CONICET, Buenos Aires, Argentina, E-mail: danielalauria76@gmail.com 
Palabras clave: control discursivo; globalización; glotopolítica; lengua española; subjetividades

A Spanish version of this article can be found in the Appendix.

I would like to start this brief essay by clarifying my locus of enunciation: the so-called Global South. My research and writing deal with Latin America, a world region with enormous (and ever-increasing) social and economic inequalities. Argentina, my home country and a more specific topic of my writings and investigations, is one of the countries most in debt to international economic organizations like the International Monetary Fund, the World Bank, and the International Bank of Development. This red ink dooms us to obeying capitalism, its dynamics of free commerce, and its mode of production - albeit to varying degrees, depending on the political party in power. My proposal herein reflects these spatial and temporal coordinates, which bear the marks of the hierarchical relations between center (the "Global North") and periphery in the current world order.

The field of language today oscillates between movements that tend to be either centripetal (expansion and unity) or centrifugal (shrinkage and diversity). In this dialectical setting, a series of specific issues must be addressed not only in scientific investigation but also in the design and implementation of public policies at both the national and regional level. The focus here should be on the trajectories and linguistic practices of vast sectors of the population whose repertoire of language use is socially differentiated from (and subordinate to) what is considered legitimate.

The local strategic agenda for a socially conscious approach must thus aim to identify and reverse the effects of linguistic inequality in the distribution of power and people's possibilities to access symbolic and material resources. In this regard, it is necessary to teach our regional variety of Spanish, as many Argentines speak this. The endo-normative linguistic instruments (grammar and punctuation handbooks, dictionaries, textbooks) of this local variety are few and largely unknown. In fact, Spanish language education in Argentina relies on teaching and reference materials put into circulation by language authorities based in Spain and with the financial backing of transnational companies. Distributed throughout the Spanish-speaking world, these materials privilege a language variety referred to as "panhispanic". Presented as a "common” variety, panhispanic Spanish is, in fact, far removed from the actual uses of language by students in our region, thus resulting in high levels of linguistic insecurity at schools. The effective implementation of bilingual intercultural education is also an urgent problem in areas where indigenous languages, the languages of recent immigrants (from Asia or Africa), and contact/border languages and/or varieties predominate. In such cases, speakers of these languages have fewer job opportunities and encounter serious difficulties when it comes to accessing information, healthcare, and justice. 
Here, however, I will be dealing with a less explored issue, at least in Spanish: the normative language-regulatory mechanisms of discursive practices (Cameron 1995; Foucault 1971) and their glottopolitical effects (Arnoux 2020). I contend that this should be a priority area.

In a great many spheres of social life - politics, economics, trade, education, religion, health, bureaucracy, and academia-science - modes of speaking and writing (prosodic, syntactic, lexical, stylistic, and textual patterns and formats) have become standardized. The constant mobility of people, goods, and capital; intense data flows, the technologizing of the word and its combination with artificial intelligence and the processing of natural language; and digital platforms and applications have all contributed to this standardization. These new discursive uses impose limitations in contemporary societies subjected to increasing cybersurveillance and monitoring, casting a blanket of silence. And this is even more starkly evident in the subaltern countries and regional blocs in the world system that often must compromise even at the discursive level in order to receive loans, join international organizations, or pass external transparency and anticorruption audits.

Using a glottopolitical approach (Del Valle 2017), I analyze these interventions and the linguistic ideologies that sustain them. This critical, speaker-engaged perspective has practical applications beyond academia and represents, in the places where it is developed, a militant, dissident alternative. This is because one of its principal aims is the search for emancipation in political, economic, cultural, scientific and, of course, linguistic and discursive terms.

According to Argentine researcher Elvira Arnoux (2020), a crucial reference among scholars of glottopolitics in Latin America, actions in the field of language should be considered the expression of broader sociohistorical processes. For this reason, Arnoux argues, these actions help configure the subjectivities necessary for each type of society at any given moment in time. Therefore, the introduction, reproduction, transformation, and/or subversion of political entities, social identities and relations, and power structures in the local, national, regional, and global sphere are all nourished by such actions.

Societal control is by no means a recent phenomenon in the history of humanity. From classical antiquity to feudalism and through the golden age of modern nation-states, actions have been taken to control society. The control of languages, language varieties, registers, and the discourses that a society produces and circulates also has a long history. In the West, rhetoric and poetics books, the arts of public speaking and writing, and correspondence manuals have influenced numerous social practices and teaching as well. The main purpose of rhetorical tradition, as we know, is to establish norms for using words in public, detailing and dictating what is considered correct. 
In recent decades, discursive control has intensified, taking on new historical meaning and a novel social function. Just as there is a lingua franca, it could be said that there are now common discursive practices that are presented as neutral and technical. In this regard, scholars working on this topic (Arnoux 2020; Arnoux and Lauria forthcoming; Becker 2020; Di Stefano 2020; Lauria 2019), have identified the following ways in which this discursive control plays out:

- Simplification of written and oral practices. The norms established for online newspaper editions are one example of this category. The type of writing expected in such publications involves short sentences, few subordinate clauses, some paragraph lengths, bold-face text segments, a lexicon free of any localisms or jargon, and an eschewal of any plays on words. Other examples include the guidelines of the plain language movement now so in vogue within the state apparatus and the business world; the increasing number of "easy-to-read" versions of diverse discursive genres; rules for the labeling and packaging of products and services; author guides for the publication of academic articles in indexed journals; and voice prompts for media announcers.

- Tempering of discriminatory features of language. This category is comprised of the norms associated with politically correct language. Its impact extends to words and expressions related to political, religious, and culture affiliations, as well as ethnicity, sexuality, gender, class, illness, disability, physical defects, age, trade, and employment. These norms are widely accepted in civil service, universities, mass media, and publishing.

- Scripting, facilitation, guidance, and correction of communicative interaction. This includes not only instructions for call center operators who contact customers to offer them products and services, but also the exchanges that take place within companies, and political campaign speeches and candidate debates. Predictive text is another such mechanism, one that automatically corrects and provides prompts for emails, chats, and instant messages as they are being drafted. Yet another, professional writing services, can be used to generate website content.

- Identification and allocation of expertise. The recurring use of fixed, unequivocal expressions and preformulated reasoning schemas in the discourses of politics, economics, health care, and international relations is an additional category. The person or institution utilizing them demonstrates that they are informed and up to date in a certain area of expert knowledge. By imposing these directives as the only type of acceptable public discourse, the contrast between different positions dissolves and matrices of monolingual meanings are created. 
Many of these mechanisms appear first in the English language before their prototypical features are faithfully replicated in other languages. When discursive patterns are standardized, automatic translators, search engines, and chatbots all function more effectively. This benefits transnational capital, which tends to do business in English, reaching different parts of the world with prospectuses, user instructions, and advertisements aimed at commercializing products and services. In the case of the Spanish language, the panhispanic policy serves as a guarantee of this linguistic homogeneity. In 2018, the Real Academic Española (RAE) - the foremost language authority of Spain - decided to address discursive codes of conduct. The resulting publication, El libro de estilo de la lengua española según la norma panhispánica [The style book of the Spanish language according to panhispanic norms], addresses grammar, vocabulary, and punctuation, along with metadiscursive aspects of written, spoken, audiovisual, and digital media.

The declarative aim of these measures is to intercede in the discursive order with the alleged aim of empowering speakers, that is, transforming the unequal distribution of linguistic capital and fostering more democratic communications. However, there are clearly ulterior political and economic motivations in these measures linked to globalization. The strategies of discursive control are part of a game of force and power relations, whose main objective is to impose public policies on peripheral countries. In Argentina, the government's adoption of so-called plain language is a requirement for the country to become a member of the Organization for Economic Co-operation and Development (OECD). And officials across the region incessantly repeat phrases imposed by international organizations, whose headquarters (and interests) are in the "Global North", to show such alignment (and compliance).

At the same time, discursive standardization responds to a push to make language functional. This correlates to a neoliberal, technocratic rationale of efficacy, efficiency, speed, and profit that has become increasingly hegemonic, part of a business logic in which recipients - even from the perspective of state agencies - are seen less as citizens and more as customers of public services.

Finally, in the hegemonic mode of production and consumption, language is a necessary condition for exchange as well as a tool that serves to organize content. Through information stored in enormous databases, then, standardization provides digital control or "intelligence" that allows individuals to be classified according to their spending habits or political leanings. Once the profiling process is complete, these individuals can then be targeted for advertising and campaigning messages.

In summary, modes of discursive control that are quickly propagating globally lay the groundwork for a new neocolonial form of domination, like that which already exists in finance and culture. In the "Global South," these linguistic and discursive interventions infringe on local identity and, when combined with 
subjectification processes, further consolidate the established order and exacerbate inequality because, as indicated above, access to resources, goods and capital is restricted to large sectors of the population.

\section{Appendix}

\section{El control de las prácticas discursivas en lengua española}

Inicio este breve ensayo explicitando mi lugar de enunciación: el llamado “sur global”. Escribo e investigo desde y sobre una de las regiones, América Latina, con mayor (y cada vez más creciente) desigualdad social y económica del mundo. Escribo e investigo también desde y sobre la Argentina, uno de los países que más dinero les debe a los organismos internacionales de crédito como el Fondo Monetario Internacional, el Banco Mundial y el Banco Interamericano de Desarrollo. Esta situación nos ata, con mayor o menor vigor según los gobiernos de turno, a una resignada obediencia al capitalismo con sus dinámicas de libre comercio y de estructura productiva. Lo que planteo a continuación se inscribe en esas coordenadas espacio-temporales, que están marcadas por las relaciones jerárquicas entre el centro ("norte global") y la periferia en el orden mundial vigente.

En la actualidad, en el campo del lenguaje, las acciones oscilan entre movimientos que tienden hacia fuerzas centrípetas (expansión y unidad) o centrífugas (contracción y diversidad). En este escenario dialéctico, debemos hacer frente, tanto desde la investigación científica como desde el diseño y la ejecución de políticas públicas, a una serie de problemáticas específicas a nivel nacional y regional que tienen como foco las trayectorias y las prácticas lingüisticas de amplios sectores de la población, que disponen de un repertorio de usos del lenguaje socialmente diferenciados (y subordinados) respecto de lo que se considera legítimo.

La agenda estratégica local para un abordaje socialmente relevante está impulsada, así, por indagar y revertir los frutos de la desigualdad lingüística en la distribución del poder y las posibilidades de acceso a recursos simbólicos y materiales. En ese sentido, se debe atender la enseñanza de la variedad regional del español, que es mayoritaria, y que no cuenta con (o cuenta con pocos y escasamente conocidos) instrumentos endonormativos (gramáticas, diccionarios, ortografías, textos escolares). En efecto, el sistema educativo se apoya en obras de referencia y didácticas que circulan en todo el mundo hispanohablante y que privilegian una variedad denominada panhispánica difundida por las academias de la lengua española con el apoyo financiero de empresas transnacionales. Esta variedad, que se presenta como “común” es, en rigor, bastante ajena a los usos concretos de nuestros estudiantes, por lo que los niveles de inseguridad lingüística 
en las escuelas son altos. Otros problemas urgentes atañen a la implementación efectiva de la educación intercultural bilingüe en áreas donde predominan lenguas indígenas, lenguas de inmigración reciente (asiáticas y africanas) y lenguas y/o variedades de contacto y/o de frontera, cuyos hablantes tienen serias dificultades para acceder a servicios de información, salud y justicia, así como se restringen sus oportunidades laborales.

Me ocuparé, sin embargo, aquí de otra problemática menos estudiada, al menos en español, y que, creo, debe ser vista como área prioritaria: los dispositivos normativos de regulación y control de las prácticas discursivas (Cameron 1995; Foucault 1971) y los efectos glotopolíticos (Arnoux 2020) que ello supone.

La constante movilidad de personas, mercancías y capitales; el intenso flujo de datos; el desarrollo de las tecnologías de la palabra y la comunicación y su combinación con la inteligencia artificial y el procesamiento del lenguaje natural, así como las plataformas y las aplicaciones digitales provocaron la uniformización de los modos (formatos y patrones prosódicos, sintácticos, léxicos, estilísticos y textuales) de decir, hablar y escribir en varias esferas de la vida social (políticas, económicas, comerciales, educativas, religiosas, terapéuticas, burocráticas y académico-científicas). Estos nuevos usos discursivos instauran límites y silenciamientos en las cada vez más monitoreadas y cibervigiladas sociedades contemporáneas. Y esto resulta aún más evidente en los países y bloques regionales que ocupan posiciones subalternas en el sistema-mundo puesto que en ocasiones para recibir préstamos monetarios, formar parte de organismos internacionales o aprobar auditorías externas de transparencia y anticorrupción deben, como contrapartida, adoptar condicionamientos incluso en el plano discursivo.

Analizo estas intervenciones y las ideologías lingüísticas que las sostienen desde el enfoque glotopolítico (Del Valle 2017). Esta perspectiva de indagación crítica y comprometida con los hablantes, que tiene una dimensión aplicada, adquiere, en los lugares en los que se desarrolla, un perfil militante alternativo, disidente ya que está entre sus principales objetivos la búsqueda de un ideal emancipador en términos políticos, económicos, culturales, científicos y, por supuesto, lingüísticos y discursivos.

La investigadora argentina Elvira Arnoux (2020), referente crucial de la escuela latinoamericana de glotopolítica, explica que las acciones en el campo del lenguaje deben considerarse como expresión de procesos sociohistóricos más generales y que, por ello, inciden en la configuración de las subjetividades necesarias para cada tipo de sociedad y para cada coyuntura. De allí que esas acciones participan en la instauración, reproducción, transformación y/o subversión de entidades políticas, identidades y relaciones sociales, y estructuras de poder en el ámbito local o nacional como regional o planetario. 
El control de las sociedades no es, en absoluto, un fenómeno reciente en la historia de la humanidad. Desde la antigüedad clásica, pasando por el feudalismo hasta en la época de auge de los Estados nacionales modernos, se implementaron variadas acciones para lograr ese propósito. El control de las lenguas, las variedades, los registros y los discursos que se producen y circulan en las sociedades tampoco lo es. En Occidente, las retóricas, las poéticas, las artes de predicar y de escribir, los manuales de correspondencia incidieron en numerosas prácticas sociales y también en la enseñanza. Como se sabe, la tradición retórica tiene como su principal función establecer normas para el ejercicio de la palabra pública, describiendo y prescribiendo lo que se considera correcto.

En las últimas décadas, se intensificó notablemente el disciplinamiento discursivo con un nuevo sentido histórico y una función social inédita. Así como hay una lingua franca, se puede decir que hay "prácticas discursivas francas" que se presentan bajo el manto de la neutralidad y el tecnicismo. Hasta el momento, hemos relevado (Arnoux 2020; Arnoux y Lauria en prensa; Becker 2020; Di Stefano 2020; Lauria 2019) los siguientes procedimientos:

- Simplificadores de las prácticas escritas y orales. Integran esta categoría las normas fijadas para las ediciones online de los periódicos que exponen un modelo de redacción basado en frases cortas, construcciones subordinadas escasas, división en párrafos y resaltes de segmentos de los textos, empleo de léxico sin localismos ni jergas, ausencia de juegos de sentido; las pautas del movimiento lenguaje claro que circula en el aparato estatal y en el ambiente empresarial; las campañas de adaptación de textos de diversos géneros a la modalidad de lectura fácil; las reglas para el etiquetado y rotulación de productos y servicios; los preceptos para la publicación de artículos académicos en revistas indexadas; las indicaciones sobre la voz para la alocución mediática.

- Atenuadores de los rasgos discriminatorios en el lenguaje. Integran esta categoría las normativas de lo que se denomina lenguaje políticamente correcto y que afecta a palabras y expresiones relativas a aspectos políticos, religiosos, culturales, étnicos, sexuales, de género, de clase, como también de enfermedades, discapacidades, defectos corporales, edad de las personas y oficios o empleos. Estas pautas tienen aceptación en la administración pública, las universidades, los medios y las editoriales.

- Guionadores, facilitadores, orientadores y correctores de la interacción comunicativa. Se incluyen no solo las instrucciones que se imparten para que los operadores de los call centers se contacten con los clientes con el fin de ofrecerles productos y servicios, sino también los intercambios en las empresas y los discursos de los políticos en campañas electorales o en debates 
proselitistas. Hay dispositivos que funcionan como predictores que dirigen y corrigen automáticamente la redacción de los correos electrónicos, chats y mensajes instantáneos. Además, hay auxiliadores de prácticas de escritura profesionales, que se usan para la generación de contenido en páginas web.

- Identificadores y asignadores de experticia. Esta categoría se relaciona con la formulación recurrente de expresiones fijas e incuestionables, así como de esquemas de razonamiento preestablecidos que se generalizan en los discursos de la política, economía, salud, relaciones internacionales para mostrar a la persona o institución que las emplea como informada y actualizada en cierta área de saber experto. Estas “consignas” se imponen como lo aceptado en el discurso público anulando la confrontación entre distintas posiciones y forjando matrices de sentidos monolingües.

Muchos de estos dispositivos surgen en lengua inglesa y las demás lenguas calcan sus rasgos prototípicos. Al uniformizarse los patrones discursivos, se facilita la acción de los traductores automáticos, los buscadores y los chatbots (o asistentes virtuales). Esto beneficia al capital transnacional que opera usualmente en inglés para que llegue vía internet o por celular con sus productos y servicios a diferentes partes del mundo a través de prospectos, indicaciones de uso y publicidades. En el caso del español, esta orientación homogeneizadora está garantizada por la política panhispánica. En 2018, la Real Academia Española decidió embarcarse por primera vez en la regulación de la conducta discursiva. Con El libro de estilo de la lengua española según la norma panhispánica, además de abordar cuestiones gramaticales, léxicas y ortográficas, se ocupa de aspectos metadiscursivos en los medios escritos, orales, audiovisuales y digitales.

Más allá de los aspectos declarativos que anuncian que estas acciones tienden a arbitrar el orden discursivo con la supuesta voluntad de empoderar a los hablantes, es decir, de transformar la distribución desigual del capital lingüístico y favorecer la democratización de la comunicación, lo cierto es que hay motivaciones políticas y económicas ligadas a la globalización que justifican estas medidas. Las estrategias de control discursivo son| parte de un juego de relaciones de fuerzas y de poder, cuyo objetivo principal es imponer políticas públicas a los países periféricos. La adopción del llamado lenguaje claro por parte del gobierno argentino es una exigencia para ingresar a la Organización para la Cooperación y Desarrollo Económico. Y los funcionarios gubernamentales repiten incesantemente frases impuestas por las organizaciones internacionales, las potencias mundiales y las empresas transnacionales, cuyas sedes (e intereses) se asientan en el "norte global" con el fin de mostrar dicho alineamiento (y acatamiento).

Asimismo, la uniformización discursiva responde a una funcionalización del lenguaje afín a la racionalidad neoliberal tecnocrática hegemónica de la eficacia, eficiencia, rapidez y lucro, propia de la lógica empresarial en la que los 
destinatarios -incluso desde las instituciones estatales- son interpelados como clientes de los servicios públicos más que como ciudadanos.

Finalmente, puesto que en el modo de producción y consumo hegemónico el lenguaje es condición necesaria de los intercambios a la vez que herramienta que opera como organizador de los contenidos, la uniformización redunda en un control o "inteligencia” digital que permite, a través de la información almacenada en grandes bases de datos, clasificar a los individuos según estándares de gastos y tendencia política, y suministrar perfiles de destinatarios para enviar mensajes publicitarios y de propaganda.

En suma, los modos de disciplinamiento discursivo que se propagan muy rápidamente a escala global fundan una nueva forma neocolonial de dominación, como lo es la financiera y la cultural. En el "sur global”, estas intervenciones lingüísticas y discursivas que atentan contra la identidad local junto con los procesos de subjetivación que implican reproducen aún más el orden establecido y refuerzan la desigualdad ya que, como se indicó anteriormente, se restringe el acceso a recursos, bienes y capitales a amplios sectores de la población.

\section{References}

Arnoux, Elvira. 2020. Modos de regulación de la discursividad: en torno a la simplificación y la uniformización. La Rivada 14. 15-36.

Arnoux, Elvira \& Daniela Lauria. forthcoming. La dimensión prescriptiva en los discursos de los instrumentos lingüísticos (gramáticas, diccionarios, ortografías, retóricas, manuales de estilo). In Isolda Carranza, Teun van Dijk \& Carmen López Ferrero (eds.), Handbook of Spanish discourse studies. London: Routledge.

Becker, Lidia. 2020. Lenguaje claro/llano/ciudadano y lectura fácil: ¿nuevas variedades de comunicación digital de masas más allá del español general/común/total o internacional/ neutro? In Sebastian Greußlich \& Franz Lebsanft (eds.), El español, lengua pluricéntrica, 223-250. Göttingen: Vandenhoeck and Ruprecht.

Cameron, Deborah. 1995. Verbal hygiene. London: Routledge.

Del Valle, José. 2017. La perspectiva glotopolítica y la normatividad. Anuario de Glotopolítica 1. 17-39.

Di Stefano, Mariana. 2020. El debate presidencial obligatorio como intervención glotopolítica. Anuario de Glotopolítica 3. 161-173.

Foucault, Michel. 1971. L'ordre du discours. Paris: Gallimard.

Lauria, Daniela. 2019. Sobre el programa 'Justicia en lenguaje claro' del Ministerio de Justicia y Derechos Humanos de la Nación (Argentina). Entremeios 18. 43-61. 